\title{
Nuclear frames in the Irish media: Implications for conversations on nuclear power generation in the age of climate change
}

\author{
Catherine Devitt \\ University College Dublin, Catherine.Devitt@ucd.ie \\ Finbarr Brereton \\ University College Dublin \\ Simon Mooney \\ Technological University Dublin
}

See next page for additional authors

Follow this and additional works at: https://arrow.tudublin.ie/ehsiart

Part of the Environmental Sciences Commons, and the Medicine and Health Sciences Commons

\section{Recommended Citation \\ Catherine Devitt, Finbarr Brereton, Simon Mooney, David Conway, Eoin O'Neill, Nuclear frames in the Irish media: Implications for conversations on nuclear power generation in the age of climate change, Progress in Nuclear Energy, Volume 110, 2019, Pages 260-273, ISSN 0149-1970, DOI: 10.1016/ j.pnucene.2018.09.024.}

This Article is brought to you for free and open access by the ESHI Publications at ARROW@TU Dublin. It has been accepted for inclusion in Articles by an authorized administrator of ARROW@TU Dublin. For more information, please contact arrow.admin@tudublin.ie, aisling.coyne@tudublin.ie,gerard.connolly@tudublin.ie.

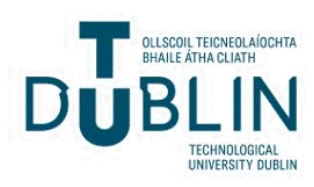


Authors

Catherine Devitt, Finbarr Brereton, Simon Mooney, David Conway, and Eoin O'Neill

This article is available at ARROW@TU Dublin: https://arrow.tudublin.ie/ehsiart/25 


\title{
Nuclear frames in the Irish media: Implications for conversations on nuclear power generation in the age of climate change
}

\author{
Catherine Devitt ${ }^{\mathrm{a}, *}$, Finbarr Brereton ${ }^{\mathrm{a}, \mathrm{c}}$, Simon Mooney ${ }^{\mathrm{b}}$, David Conway ${ }^{\mathrm{a}}$, Eoin O'Neill ${ }^{\mathrm{a}, \mathrm{c}, \mathrm{d}}$ \\ ${ }^{\text {a } U C D ~ E n v i r o n m e n t a l ~ P o l i c y, ~ S c h o o l ~ o f ~ A P E P, ~ U n i v e r s i t y ~ C o l l e g e ~ D u b l i n, ~ D u b l i n ~ 4, ~ I r e l a n d ~}$ \\ ${ }^{\mathrm{b}}$ Environmental Sustainability \& Health Institute (ESHI), Dublin Institute of Technology, Dublin 7, Ireland \\ ${ }^{\mathrm{c}}$ UCD Earth Institute, University College Dublin, Dublin 4, Ireland \\ ${ }^{\mathrm{d}}$ UCD Geary Institute, University College Dublin, Dublin 4, Ireland
}

A R T I C L E I N F O

\section{Keywords:}

Nuclear power generation

Climate change

Media framing

Public debate

\begin{abstract}
A B S T R A C T
Keeping within the temperature limits set by the Paris Agreement on climate action will be a significant challenge. Nuclear power generation may contribute to achieving these targets, however, there are significant environmental, economic and health risks attached. Using qualitative and quantitative methods, this paper explores how nuclear power generation is framed in the Irish print media, and discusses the implications of these frames for how nuclear power is perceived within the context of climate change mitigation in Ireland. Two Irish broadsheet papers, the Irish Times and the Irish Independent were selected for data collection, focusing on Chernobyl and Fukushima incidents. The prevalence of informational and balanced articles suggest that to some extent, an open debate on nuclear is already occurring. Nevertheless, significantly more articles take an antinuclear stance (34\% in 1986 and 27.5\% in 2011) than pro-nuclear (2.1\% in 1986 and 3.3\% in 2011), reflecting the lack of public appetite for nuclear power. This may limit the potential for a wider debate to occur within the context of reducing domestic emissions. Considering the urgency of addressing climate change, a full and balanced societal debate on how nuclear power, other energy alternatives (e.g. wind) and the energy sector more generally, can contribute to national climate policy targets may be necessary.
\end{abstract}

\section{Introduction}

There is mounting evidence to show that the timeframe for preventing dangerous climate change levels is quickly diminishing (IPCC, 2014). To keep within safe temperature limits, it will be necessary to reduce greenhouse gas emissions by at least $80-90$ percent by 2050 (Jones and Glachant, 2010; Pfenninger and Keirstead, 2015). The landmark Paris Agreement on Climate Change agreed to hold "the increase in the global average temperature to well below $2{ }^{\circ} \mathrm{C}$ above preindustrial levels" and pursue efforts "to limit the temperate increase to $1.5^{\circ} \mathrm{C}$ above preindustrial levels" (UNFCCC, 2015, p.2). However, doubt was cast on the effectiveness of pledges from individual countries on climate action in meeting the $2{ }^{\circ} \mathrm{C}$ threshold (Rogeli et al., 2016; Rockström et al., 2016) made even more salient in the context of the recently announced US withdrawal from the agreement in its current form. ${ }^{1}$

\subsection{Nuclear power in the age of climate change}

Due to the high levels of emissions produced, assessing energy inputs is essential for developing and implementing mitigation policies (Bibas et al., 2015). Global energy consumption is expected to increase significantly in the short to medium term, which has led to energy security becoming an important part of energy policy debates (Corner et al., 2011). While the concept of energy security has been described as 'slippery' in the international literature (Chester, 2010) we take the concept to refer to "unimpeded access or no planned interruptions to sources of energy" (Chester, 2010 p887). Some authors argue that nuclear power generation can contribute to improving energy efficiency and security, reducing pollution and emissions, and allow a diversification of electricity generation (Teräväinen et al., 2011; Paska and Surma, 2014; DeLlano-Paz et al., 2015).

As of 2015, electricity in thirty countries around the world was

\footnotetext{
* Corresponding author.

E-mail address: Catherine.Devitt@ucd.ie (C. Devitt).

${ }^{1}$ While legally the US cannot withdraw until 2020, President Trump has suggested that the US may potentially re-enter a revised agreement, see https://www.

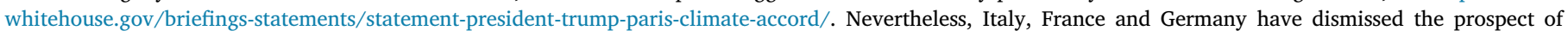
revising the Paris Accord.
} 
generated using nuclear power, representing approximately 11 per cent of the world's electricity generation (Bruckner et al., 2014). Within the European Union, nuclear power provides 53 percent of the EU's carbonfree (at the point of production) ${ }^{2}$ electricity (World Nuclear Association, 2015). In light of the goals established by the Paris Agreement, nuclear power generation has come under greater focus, albeit mostly among agencies in support of nuclear power generation (New Nuclear Watch, 2015; Cooper, 2016; Rose et al., 2017). Pro-nuclear organizations such as the International Atomic Energy Agency (2016) argue that in order to meet the $2{ }^{\circ} \mathrm{C}$ temperature target, a 41 percent reduction in total energy related $\mathrm{CO}_{2}$ emissions and a 70 percent reduction in power sector emissions is required. They also contend that the contribution of nuclear energy to decarbonizing the electricity sector could result in annual $\mathrm{CO}_{2}$ emission reductions of 13 percent of the global emissions reduction required in the power sector, and over 20 percent reduction in emissions in the energy sector by 2050 (NEA and IEA, 2015). However, others argue that to achieve even a slight reduction in $\mathrm{CO}_{2}$ emissions by 2050, between 1500 and 2000 new reactors would be required (Smith, 2006; Makhijani, 2007).

A highly contentious issue, nuclear power remains part of the energy mix in the UK (Pfenninger and Keirstead, 2015), while other European countries, such as Italy and Switzerland are currently phasing out nuclear power (Helm, 2014). Although the likelihood of a nuclear accident is small (OECD, 2010), experience of nuclear incidents shows that the environmental, economic, health and general societal implications of a nuclear incident are hugely significant. Nuclear reactors require large amounts of water, and must be located in areas close to large water bodies, such as coastal regions. These same regions are typically where the highest population concentration exists; increasing economic and social risks should a nuclear accident occur. Coastal reactors are also particularly vulnerable to sea level rise, coastal erosion and flooding as well as changes in water temperature, quality, or availability (Kopytko and Perkins, 2011). A nuclear incident can alter the public and policy response on nuclear power generation. For example, the Fukushima Daiichi incident ${ }^{3}$ in Japan was used to justify nuclear power generation and reaffirm policy positions (as in the UK), as well as alter the policy direction (which occurred in Germany) (Wittneben, 2012).

\subsection{Ireland and climate change}

The Climate Action and Low Carbon Development Act (2015), sets out the national objective to transition to a low carbon, climate resilient and environmentally sustainable economy by 2050 . This objective aims to achieve an aggregate reduction in $\mathrm{CO}_{2}$ emissions of at least 80 percent across electricity generation, buildings and the transport sector, and to achieve carbon neutrality in the agricultural and land use sector. The Act provides for the preparation of five-yearly National Mitigation Plans, which will determine how Ireland will reduce its greenhouse gas emissions in line with EU legislation and international commitments under the United Nations Framework Convention on Climate Change (UNFCCC). Ireland, which is a high per capita emitter of greenhouse gases, faces challenging decisions in determining the appropriate pathway to transitioning to a low carbon society. It has the highest dependency on imported fossil fuels for electricity generation in Europe, and currently imports approximately 85 percent of its energy sources (Sustainable Energy Authority of Ireland, 2016). Energy sector

\footnotetext{
${ }^{2}$ For example, in an Irish context the Moneypoint power station (the State's largest electricity generation station) is a coal fired station producing sulphur dioxide and $\mathrm{CO} 2$ emissions during electricity production (point of production). An electric vehicle powered by this electricity produces no additional emissions (non-point of production).

${ }^{3}$ Following a major earthquake, a 15-m tsunami disabled the power supply and cooling of three Fukushima Daiichi reactors, causing a nuclear accident on 11 March 2011: http://www.world-nuclear.org/information-library/safetyand-security/safety-of-plants/fukushima-accident.aspx.
}

emissions - from power generation, oil refining, and peat burning accounts for approximately 19 percent of total greenhouse gas emissions (Environmental Protection Agency, 2015; SEAI, 2016). Power generation itself accounts for the greatest percentage of emissions over 95 percent- within the energy sector (EPA, 2015). Under current projections, Ireland will miss its 2020 climate and energy targets, and significant challenges will need to be overcome if it is to meet its projected 2030 targets and achieve a realizable pathway towards decarbonization (Climate Advisory Council, 2016; EPA, 2017).

\subsection{Ireland's position on nuclear power generation}

In the late 1960s, plans for a nuclear power plant at Carnsore Point, Co. Wexford (south-east Ireland) were proposed by the Nuclear Energy Board (an agency charged with the responsibility of pursuing policy on nuclear in Ireland) to meet the growing demand for power in Ireland (Leonard, 2006). These plans never materialized; public opposition has been cited as one reason (Fitzgerald, 2011). Other reasons cited include Ireland's relatively small power system; incorporating a large nuclear power plant into the system would be economically and practically challenging. However, developments in the size of reactors have been identified as possibly suiting the Irish system (SEAI, 2011). While currently, nuclear power generation is prohibited by Irish legislation (Department of Communications, Energy and Natural Resources, 2015), Ireland imports nuclear generated electricity from the Welsh Wylfa nuclear power station via an East-West interconnector under the Irish Sea since 2012. A small number of analysts contend that nuclear power needs to be considered as part of the energy mix in determining how best to respond to Ireland's energy needs (Grimes, 2015), and calls were made in 2008 by the then Minister for Communications, Energy and Natural Resources, for an open debate on nuclear (Irish Times, 2008).

Currently, the anti-nuclear debate in Ireland is driven by safety concerns over Ireland's close proximity to the Sellafield nuclear plant in Cumbria on the north-west coast of England. These concerns have resulted in the Irish government making formal complaints regarding the facility to the British government. In 2016, the Department of Communications, Climate Change and Environment published a report on impacts to the Irish economy should a nuclear incident take place close to Ireland (Curtis et al., 2016). This was followed by a study on the potential radiological impacts for Ireland based on a number of hypothetical accident scenarios (EPA, 2016). Although a Green Paper on energy policy acknowledged the countries anti-nuclear position, it also suggested the need to "consider in greater depth the potential economic and technical implications, or ... to test public acceptance of nuclear generation located on the island of Ireland" (DCCAE, 2014, p.50). The subsequent White Paper on Ireland's transition to a low carbon energy future restated Ireland's prohibition on nuclear power generation; however, it gave no indication towards the need for public debate (DCCAE, 2015).

\subsection{Aims and objectives}

Considering the complexity of climate change, and the urgency to take climate action, an informed societal debate on climate policy is necessary and media coverage, among other variables, can play an important role in influencing how the public and governments respond through policy choices (Prati and Zani, 2012; Grossman, 2015). As Europe seeks to transition to a low carbon economy, the need for such a societal discussion on how this transition can take place and how the EU's energy and climate targets can be achieved will become increasingly important.

This paper seeks to explore how nuclear power, specifically the Fukushima and Chernobyl nuclear accidents, is reported on and framed in sections of the Irish print media, and drawing on this analysis the subsequent implications for wider debates on the potential role of nuclear power in climate change mitigation in Ireland. While there are arguments for (reducing conventional power station pollution and 
emissions $^{4}$ (Teräväinen et al., 2011; DeLlano-Paz et al., 2015)) and against (potential for accidents, particularly in coastal regions (Kopytko and Perkins, 2011)) nuclear power, given the current split in nuclear power generation in the EU, we expect that the analysis in this paper may also be applicable to similar countries where nuclear power is absent, but public debate is ongoing, particularly where other alternative sources of energy have faced much opposition (for example hydraulic fracking and wind turbines in an Irish context). As there are currently no studies on the media framing or public perception of nuclear power generation within an Irish context, the results may also help contribute to and further this discussion, as well as add to existing international literature on the media reporting of nuclear power and the wider relationship between the media and environmental policy. Additionally, the qualitative analysis in the paper builds upon the statistical analysis in Wang et al. (2014) by exploring in-depth the sentiment, tone, diversity of view-points, and editorial angle in the articles, for example the focus on human interest pieces for Fukushima. ${ }^{5}$

The paper proceeds as follows, the next section describes media framing in the context of nuclear power, the following section describes the method, while the subsequent sections outline the results and discussion of findings and implications, before the final section offers our conclusions.

\subsection{Making sense of media reporting: what are media frames?}

A key approach to understanding how media describe and report on a particular topic is to identify and analyze what are known as media frames. Frames are the particular angle or viewpoint from which a news story is told. D'Angelo (2017, p.1) defines a media frame as "a written, spoken, graphical, or visual message modality that a communicator, by means of a technological channel, uses to contextualize a topic, such as a person, event, episode, or issue, within a text." Media frames generally fall under two categories: i) news stories as setting a particular intentional agenda, and ii) news stories as reflecting nuanced viewpoints and perspectives that although less intentional, are reflective of, and complement how society generally perceives and makes sense of a particular issue (Entman, 1989, 1991). Entman (1993, p.52) describes framing as the process of selecting aspects of a societal viewpoint and making them more salient, or central, in text form so as to promote a particular problem definition and interpretation. Frames are therefore, an essential component of communicating effectively.

The central dimensions of framing in news stories are the topic of focus or selection, and the saliency or importance attached to the topic (Entman, 1993). While not essentially made explicit, this selection and saliency manifests itself via the inclusion or exclusion of certain keywords, images, or phrases, which endorses and legitimizes prevailing opinions within society (Entman, 1993). Understanding how framing of a topic works is important because the manner in which a news story is communicated has implications for how society in general, and policy makers more specifically, form perceptions and respond to that topic (Entman, 1989; Cannon and Müller-Mahn, 2010). This process takes place within a complex set of interactions.

- Public opinion influences what and how news stories are communicated (this helps sell news stories), and this same opinion is in turn, shaped by media content (Gamson and Modiglian, 1989).

- Media frames influence policy makers by reflecting what the public think, and how, about a particular issue. In turn, public opinion is influenced by the scientific, political and economic discourses communicated by policy makers (Gamson and Modigliani, 1989;

\footnotetext{
${ }^{4}$ For a description of nuclear power's fuel cycle emissions see Lenzen (2008).

${ }^{5}$ In a centrally planned country such as China, where media is closely controlled by the state, opinion pieces that reflect a wide diversity of views and human interest articles are largely absent.
}

Castrechini et al., 2014).

- Hence, media coverage can be understood as an indicator for public opinion (Neresini and Lorenzet, 2014).

Importantly, the efficiency of media frames relates to their potential to draw attention away from alternative frames towards specific aspects of communication content (Entman, 1993; Bayulgen and Arbatli, 2013). The strength of the frame will direct the level of response: if the recipient of the information or communication holds little or no information on alternatives, the dominant frame will have greater influence (Entman, 1993).

\subsection{The role of media in framing public discourse about nuclear energy}

The media plays an important role in informing how society perceives and responds to a particular risk. The contention has been made that media coverage is often determined by the need to excite the public, rather than inform, and consequently reporting only takes place following a dramatic event (Singer and Endreny, 1993). Research into how the media report on risk has identified problems of sensationalism, bias and inaccurate reporting (Allan, 2002; Carvalho and Burgess, 2005), to the point where even minor risks can attract considerable media focus (Perko et al., 2012). However, in terms of nuclear, Singer and Endreny (1993) also observed that the media fail to report on the long-term hazards of nuclear energy, and through the media's use of what Culley and Angelique (2011) define as 'nukespeak' (i.e., euphemistic rhetoric and jargon often used to describe nuclear weapons, power etc.), the public are often excluded from the discussion. Social science research reveals some divergence between what media report about nuclear energy and its well-documented risks. Gamson and Modigliani (1989) found that media framed nuclear energy in terms of benefits resulting from technological advancement.

Several studies have examined news coverage of nuclear power in newspapers, the majority of which are conducted around the context of a nuclear incident occurring (Table 1). A number of studies confirm a strong correlation between media tone and public opinion of nuclear power, whether it was in favor or not of nuclear power (Stephens et al., 2009; Neresini and Lorenzet, 2014; Morrone et al., 2012). The policy context is also important. In the United Kingdom, media reporting played an important role in legitimizing the UK government's rebranding of nuclear as playing an important role in climate mitigation public opposition to nuclear power decreased when the UK government announced in 2008 that nuclear power would play a role in climate change mitigation (Doyle, 2011). Wittneben (2012) observed that the Fukushima incident received considerable in-depth attention in the German media for a number of weeks, whereas in the UK, media focus was less drastic, shying away from framing the incident as a catastrophe. These observations mirror the contrasting policy responses in both countries - the UK government has committed to increasing nuclear power generation into the future whereas the German government has decided to temporarily shut down older nuclear reactors and all nuclear power generators were examined.

\section{Method}

\subsection{Data collection}

Despite the increasing popularity of the Internet and social media, newspapers remain a very important source of environmental-related information (Boykoff and Roberts, 2007; Boykoff \& Rajan, 2007). Ireland's two most widely circulated broadsheet newspapers - the Irish Times (IT) and the Irish Independent (II) - were selected for data collection. These are the only two Irish broadsheet newspapers whose publication span the relevant search periods. The combined print and digital readership for each newspaper is over 400,000 for the IT and over 600,000 for the II (National Newspapers of Ireland, 2015). Broadsheet newspapers typically have greater influence on policy than other 
Table 1

Overview of studies that conduct analysis of media framing of nuclear power.

\begin{tabular}{|c|c|c|}
\hline Authors & Focus & Results \\
\hline $\begin{array}{l}\text { Culley et al., } \\
2010\end{array}$ & $\begin{array}{l}\text { Content analysis of proposed nuclear reactors in Georgia, United } \\
\text { States }\end{array}$ & $\begin{array}{l}\text { Newspapers presented a balanced view, with pro- and anti-nuclear arguments } \\
\text { comprising discussion on the economic and environmental benefits and risks. }\end{array}$ \\
\hline $\begin{array}{l}\text { Perko et al., } \\
2012\end{array}$ & $\begin{array}{l}\text { Content analysis of printed and spoken media reporting on a minor } \\
\text { nuclear event in Slovenia }\end{array}$ & $\begin{array}{l}\text { Analysis identified high-intensity media coverage, political debate, emotional response } \\
\text { and safety concerns, and associations with large-scale incidents such as Chernobyl. }\end{array}$ \\
\hline Lazic, 2013 & $\begin{array}{l}\text { Content analysis of reporting of the Fukushima accident in three US } \\
\text { newspapers }\end{array}$ & $\begin{array}{l}\text { Newspaper frames comprised concerns regarding the economic costs, issues around } \\
\text { responsibility, and conflicts of opinion between experts and officials. }\end{array}$ \\
\hline Koerner, 2014 & $\begin{array}{l}\text { Content analysis of three major nuclear incidents (Three Mile Island, } \\
\text { Chernobyl, and Fukushima) in a number of international } \\
\text { newspapers }\end{array}$ & $\begin{array}{l}\text { The majority ( } 70 \text { percent) of headlines were negative in tone, with over } 50 \text { percent of } \\
\text { articles referring to the negative consequences of health, safety, and the environment. } \\
\text { Media framing of nuclear is "highly consistent" with government policy on nuclear } \\
\text { power. }\end{array}$ \\
\hline $\begin{array}{l}\text { Wang et al., } \\
\qquad 2014\end{array}$ & $\begin{array}{l}\text { Content analysis of news articles related to nuclear power in two } \\
\text { Chinese newspapers }\end{array}$ & $\begin{array}{l}\text { Pro nuclear and informational articles were dominant themes - with an emphasis on } \\
\text { safety and the environmental benefits. Anti-nuclear articles were less prevalent. }\end{array}$ \\
\hline
\end{tabular}

sources of media (Carvalho and Burgess, 2005).

There is value to conducting longitudinal analysis on nuclear power in the media (Culley et al., 2010). Two incidents were chosen for this study to identify if changes in media framing occurred over time. Using search tools available in two digital repositories (ProQuest Historical Newspaper Database for IT coverage, and the Irish Newspaper Archive for the II coverage), searches were customized to the selected newspapers. The search term "nuclear" and the incident names (i.e., Chernobyl or Fukushima) were applied over an extended period. Fig. 1 presents the frequency of all nuclear-related broadsheet media coverage over a 40-year period of 1976-2016. There are clear fluctuations in nuclear-related coverage, with nuclear stories peaking with the Chernobyl incident in 1986 but a less profound oscillation in 2011 coinciding with the Fukushima incident.

In order to refine the sample, a customized seven-month time-period around each of the two specified nuclear incidents - one month prior to the incident, the month of the incident, and five months after - was selected to allow for inclusion of sufficient coverage of both incidents. After excluding news articles that only loosely referred to nuclear energy and/or either of the two incidents, a combined total of 2060 articles were returned using the specified search terms and parameters for each newspaper database. 1360 articles were yielded for the period
Table 2

Number of articles identified for each paper and each incident (i.e. pre- and post-Chernobyl 1986 and Fukushima 2011).

\begin{tabular}{llll}
\hline Newspaper & Chernobyl & Fukushima & Total \\
\hline The Irish Independent & 239 & 178 & 417 \\
The Irish Times & 535 & 273 & 808 \\
Total & 774 & 451 & 1225 \\
\hline
\end{tabular}

26th March to 26th October 1986 (Chernobyl) while 700 articles were yielded for the period 11th February to 11th September 2011 (Fukushima). All duplicate articles, advertisements, non-news articles (e.g. film reviews) were removed. This reduced the final sample to a total of 1225; comprising 774 articles over the period pertaining to Chernobyl and 451 articles over that pertaining to Fukushima (Table 2).

\subsection{Data analysis: using content analysis to understand media}

This social science study employed both a quantitative and qualitative content analysis approach to explore how sections of the Irish print media frame nuclear energy (in association with two nuclear

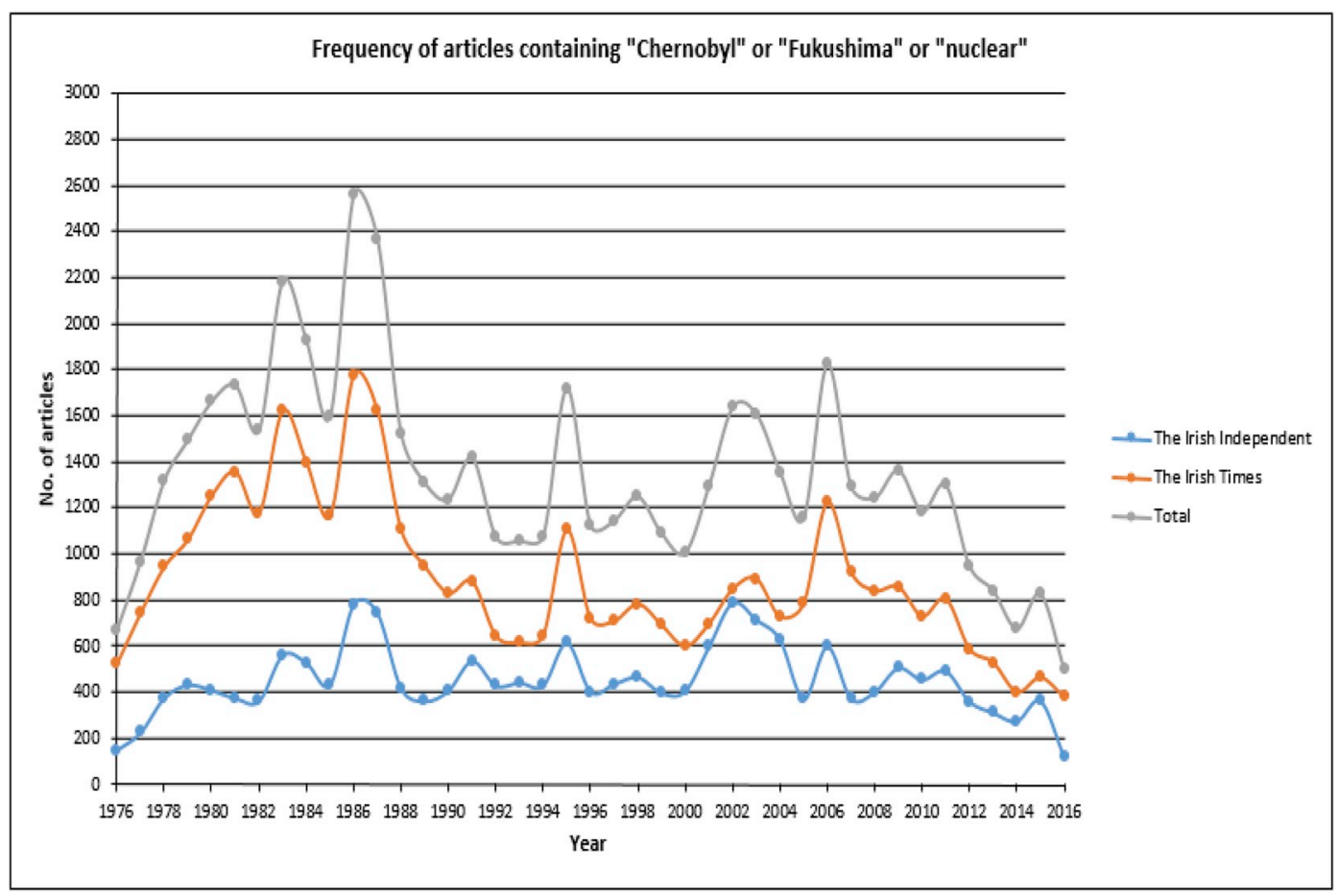

Fig. 1. Frequency of articles containing the words Chernobyl, Fukushima or nuclear. 
Table 3

Themes and coding rules (adapted from Wang et al., 2014). Note: See Appendix Table A1 for the sample articles.

\begin{tabular}{|c|c|}
\hline Theme & Coding rule \\
\hline Pro-nuclear & $\begin{array}{l}\text { Focus on data, arguments and views that support and/or favourably portray nuclear power. } \\
\text { Example article: More power to us if we choose nuclear option. The Irish Times, } 25 \text { August } 2011 .\end{array}$ \\
\hline Anti-nuclear & $\begin{array}{l}\text { Focus on data, arguments and views that oppose and/or unfavourably portray nuclear power. } \\
\text { Example article: Alliance rejects Sizewell nuclear reactor. The Irish Times, } 6 \text { May } 1986 .\end{array}$ \\
\hline Balanced & $\begin{array}{l}\text { Focus equally on data, arguments and views that support and/or favourably portray and oppose and/or unfavourably portray nuclear power. } \\
\text { Example article: Europe's reactors face natural disaster testing. The Irish Independent, } 16 \text { March } 2011 .\end{array}$ \\
\hline Informational & $\begin{array}{l}\text { Focus on general information about nuclear power with limited or no pro- and/or anti-nuclear spin. } \\
\text { Example article: All you ever wanted to know about nuclear energy. The Irish Independent, } 7 \text { May } 1986 .\end{array}$ \\
\hline
\end{tabular}

incidents). Content analysis is unlimited in its applicability to a variety of research areas due to the centrality of communications in public policy. It allows for a "systematic analysis of detecting meaning, identifying intentions and describing trends in communication content" (Bayulgen and Arbatli, 2013, p.516), which helps in describing its application across a range of environmental policy topics - including the framing of flood risk (Escobar and Demeritt, 2014; Devitt \& O'Neill, 2016), and climate change (Schmidt et al., 2013; Wagner and Payne, 2015). It is also widely used to examine media communication and content (Weber, 1990).

- A qualitative approach examines the context and content of language used in a news story. By going "beyond mere word counts", qualitative content analysis allows the researcher to identify inferred as well as explicit meaning inherent within communication text such as a news story (Hsieh and Shannon, 2005).

- Quantitative content analysis is concerned with identifying the frequency of certain themes, words or phrases used to communicate a topic (see Jupp and Norris, 1993; Culley et al., 2010; Wang et al., 2014; Neresini and Lorenzet, 2014).

The overall objective of qualitative analysis is to develop what is known as a thematic structure - in other words, a network of headings which describes conceptually the meaning underpinning a specific set of data (in this case, news text). This study followed a directed (deductive) qualitative content analysis approach (Hsieh and Shannon, 2005; Macnamara, 2005), whereby a pre-determined thematic framework (i.e., a framework already developed by similar research) was adapted from Wang et al.'s (2014) study on an analysis of media framing of nuclear energy in China (Table 3). ${ }^{6}$ Wang et al.'s (2014) framework provided a useful guide for analysis as they put forward robust, succinct themes to describe media reporting.

Data analysis comprised the following (Fig. 2);

- All newspaper articles for the II and IT were downloaded as print article scans in PDF format and subsequently saved to enable analysis offline.

- Article titles from the II and the IT were exported to excel and sorted accordingly in separate spreadsheets for each event (Chernobyl and Fukushima).

- The data for each of the seven-month time periods were categorized and sorted to pre-determined themes, using the coding rules put forward by Wang et al. (2014) (Tables 3 and 4). Coding rules are the specific guidelines or set of instructions that are applied to assist in the interpretation of what was being said in a text.

- These themes related to whether or not news stories were pro-nuclear (articles that support nuclear power), anti-nuclear (articles that oppose nuclear power), or informational (articles comprising general information). In addition, we applied the theme 'balanced' to reflect

\footnotetext{
${ }^{6}$ The study design was informed by process steps and guidelines specified by Macnamara (2005) and others (Krippendorff, 2003; Elo and Kyngäs, 2008; Altheide and Schneider, 2012).
}

articles that both opposed and supported nuclear, similar to Culley et al. (2010). ${ }^{\text {? }}$

- News content categorized to each theme was reviewed a number of times by the researcher. Articles were read multiple times $(\geq 3)$ in line with rigorous procedure to ensure avoidance of duplicate articles/jump lines, and compatibility with the thematic framework and coding rules.

- The media content (or frames) that determined article allocation to each theme was analyzed in line with existing process steps as specified by Macnamara (2005) and Elo and Kyngäs (2008). ${ }^{8}$ Where several themes (sub-themes) were present, the dominant theme (dominant sub-theme) was established based on centrality to article topic, and relative proportion to the text. Inapplicable articles (i.e. those mentioning nuclear power in passing or in a non-civilian scenario) were excluded from the final dataset but nevertheless noted to ascertain the full context in which nuclear power was mentioned. Relevant articles were recorded by title in a single document and demarcated by publication, and theme (subthemes) and dates. ${ }^{9}$ Articles which made direct reference to the temporally correspondent nuclear incident were denoted by a symbol.

- Articles under each thematic category were subsequently sorted into what are known as subthemes in line with the frame analysis process described in the preceding bullet point. These subthemes were also adopted based on a framework developed by Wang et al. (2014) (Table 4), and coding rules applied to help sort and categorise relevant articles. Subtheme labels were affixed to each article title in Microsoft Excel in an adjacent column.

- Simultaneously with the frame analysis of articles, they were assessed for sentiment, tone, diversity of view-points, and editorial angle.

- Following completion of analysis, article totals for each theme and subtheme were calculated using Microsoft Excel and tabulated thereafter.

\footnotetext{
${ }^{7}$ As acknowledged by Wang et al. (2014), media communication in Western countries connects policymakers and the public, whereas in China (where Wang et al. (2014) based their study), media communication is based on top-down dissemination to the public.

${ }^{8}$ The content and nature of frames were accordingly identified and analyzed for the four primary news framing device categories outlined by Pan and Kosicki (1993): syntactical structure (sequential organization and treatment of structural elements, e.g. article headline, lead etc.), script structure (order of and emphasis on story events/components during beginning, climax etc.), thematic structure (combination and nature of events cited, sources quoted etc.) and rhetorical structure (adoption and manipulation of symbolic devices, e.g. catchphrases, metaphors, visuals etc.). Additional reference points such as Tankard's (2001) list of 11 focal points for identifying framing were consulted to facilitate prompt detection. To address 'macro frames' (e.g. level of priority and mode of reporting) of thematic content, further regard was given to newspaper article types, as specified by Hill and Breen (1977), Harrower and Elman (2012) and Batty and Cain (2016).

${ }^{9}$ The complete list of article headlines, sorted by newspaper, theme and subtheme, is available on request.
} 


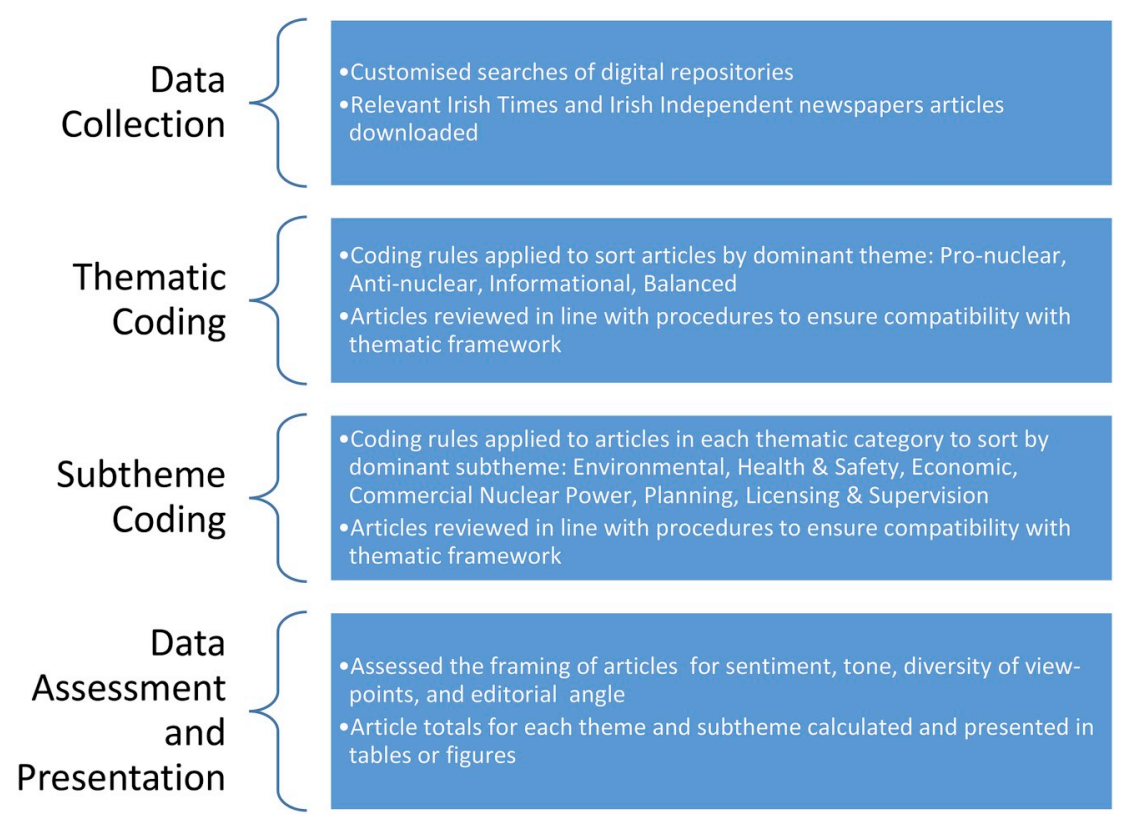

Fig. 2. Methodological summary guide.

Table 4

Subthemes and coding rules (adapted from Wang et al., 2014). Note: See Appendix Table A2 for the sample articles.

\begin{tabular}{|c|c|}
\hline Subtheme & Coding rule \\
\hline Environmental & $\begin{array}{l}\text { Focus on environmental impacts of nuclear power and the potential for and existence of environmental problems and/or solutions. Nuclear } \\
\text { power may degrade the environment via leakage of radioactive materials and nuclear waste but may also benefit the environment by } \\
\text { reducing carbon dioxide emissions. } \\
\text { Example article: Radiation in sea must be cut: MP. The Irish Independent, } 17 \text { July } 1986 .\end{array}$ \\
\hline Health and safety & $\begin{array}{l}\text { Focus on health and safety issues relating to nuclear power and measures used to prevent and control nuclear accidents and/or health } \\
\text { ramifications. Nuclear power infrastructure and precautions may or may not be sufficient to prevent and withstand nuclear accidents and } \\
\text { minimize dangers to human health. } \\
\text { Example article: Four Japanese mothers show traces of radioactive milk. The Irish Independent, } 22 \text { April } 2011 .\end{array}$ \\
\hline Economic & $\begin{array}{l}\text { Focus on economic dimensions of nuclear power and its importance to national and international economies and energy supplies. Nuclear } \\
\text { power may offer economic advantages (low transportation costs and low operation costs) and disadvantages (financial losses and industry } \\
\text { knock-on effects arising from disaster). } \\
\text { Example article: Tokyo bucks weak trend in regions' stocks. The Irish Times, } 16 \text { June } 2011 \text {. }\end{array}$ \\
\hline Planning, licensing and supervision & $\begin{array}{l}\text { Focus on planning, licensing and supervision processes relating to nuclear power and the policymaking role of governments and } \\
\text { organizations. Regulations for nuclear planning, plant operation, approval of new reactors and radiation monitoring may or may not be } \\
\text { adequate. } \\
\text { Example article: Non-nuclear states join in concern. The Irish Times, } 17 \text { September } 1986 .\end{array}$ \\
\hline Commercial nuclear power & $\begin{array}{l}\text { Focus on information about commercial nuclear power, i.e. past, present and/or future nuclear power industries. Aspects such as power } \\
\text { plant location, size, number of employees, gross electrical capacity, financing and government support may determine the status and level } \\
\text { of functionality of nuclear power industries. } \\
\text { Example article: France at home with N-power. The Irish Times, } 8 \text { September } 1986 \text {. }\end{array}$ \\
\hline
\end{tabular}

Table 5

Number and percentage of articles for both newspapers for each event (adapted from Wang et al., 2014).

\begin{tabular}{llllll}
\hline Event & Pro-nuclear & Anti-nuclear & Balanced & Informational & Total \\
\hline Chernobyl & $16(2.1 \%)$ & $264(34.1 \%)$ & $65(8.4 \%)$ & $429(55.4 \%)$ & 774 \\
Fukushima & $15(3.3 \%)$ & $124(27.5 \%)$ & $31(6.9 \%)$ & $281(62.3 \%)$ & 451 \\
Total & $31(2.5 \%)$ & $388(31.7 \%)$ & $96(7.8 \%)$ & $710(58 \%)$ & 1225 \\
\hline
\end{tabular}

\section{Results}

\subsection{Overview}

The greatest number of articles during the seven month time period of analysis for both events focused on stories that were informational (710) followed by anti-nuclear (388). Only 31 were pro-nuclear (Table 5). Table 5 reflects the overall picture for both incidents regarding the distribution of stories according to each theme, i.e. pro- nuclear, anti-nuclear, balanced or informational from both newspapers.

It is noteworthy (not shown in table) that in the month prior to both incidents, there were nuclear-related articles (53) published in both newspapers ${ }^{10}$. However, pre-incident articles were more prevalent in the period prior to the Chernobyl incident (44) compared with Fukushima (9). Irish media attention in early 1986 was particularly focused upon environmental and health and safety concerns at Sellafield with 25 of the articles being anti-nuclear. However the majority of articles published in the month preceding Fukushima (5 out of 9) were pro-nuclear. Whilst this shows that there was some news coverage of the nuclear issue before these major incidents, $96 \%$ of the articles analyzed covered the time period after these incidents, with the majority generating discussion in response to them.

Overall, there were more articles on nuclear pre- and post-Chernobyl, compared to Fukushima, which may be explained by the European

\footnotetext{
${ }^{10}$ Nuclear-related articles published in the month preceding the two nuclear incidents of interest represented $4 \%$ of all news articles extracted for analysis.
} 


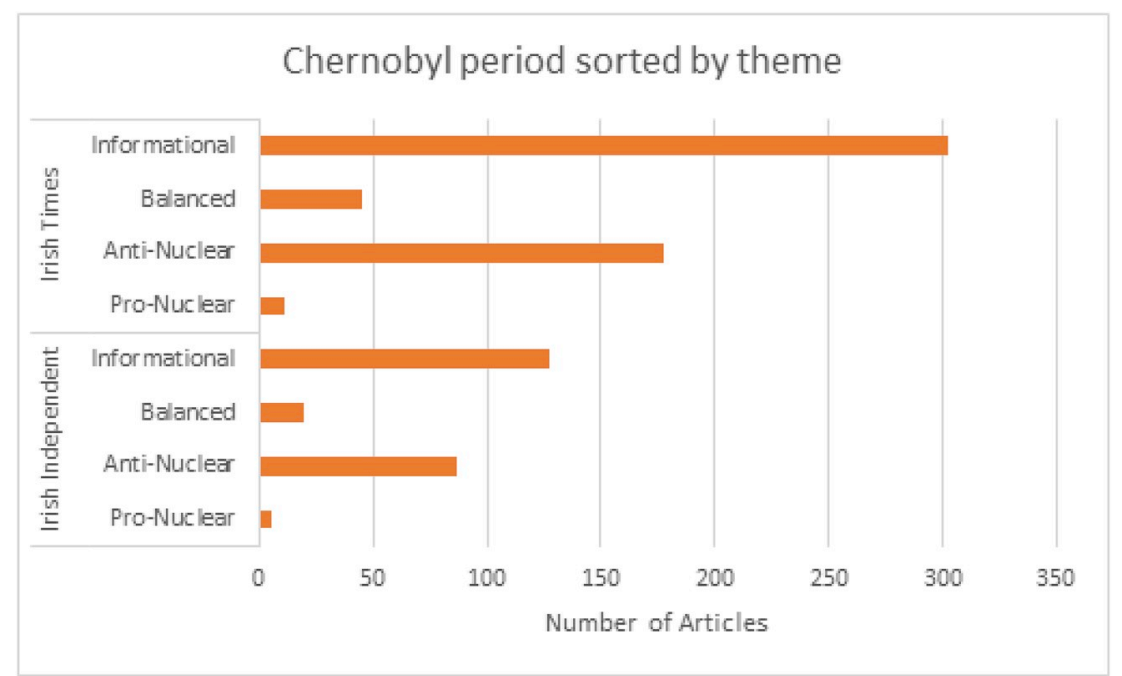

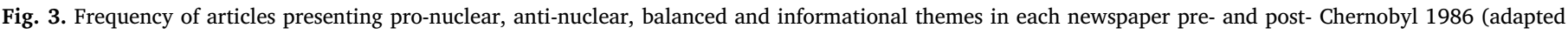
from Wang et al., 2014).

context of the Chernobyl incident, and its relative proximity to Ireland. Although the IT published over twice as many nuclear-related articles pre- and post- Chernobyl, interestingly there was little difference in the thematic prevalence found between the two broadsheets. There were more perceptible thematic differences during the pre-and postFukushima incident, with the II publishing relatively more anti-nuclear articles whereas the IT published more informational articles. The following explores the framing of each incident in more detail.

\section{Chernobyl}

\subsection{Overview}

Of the overall number of articles pre- and post-Chernobyl, most focused on health and safety concerns (generally falling into the category of informational), and issues around planning, licensing and supervision (Figs. 3 and 4). There was little notable difference in the relative prevalence of sub-themes found between the newspapers.

\subsection{Anti-nuclear articles}

One third of media articles on Chernobyl were anti-nuclear. Exploring these anti-nuclear articles (Table 6), a total of 176 articles related to health and safety concerns, with coverage peaking in the month succeeding the incident and remaining steady thereafter in spite of an overall decline. While there was little variation between the IT 'anti-nuclear' articles and II, in the IT there was twice as much emphasis on health and safety aspects, occasionally eschewing Chernobyl, Ireland and Sellafield to include focus on incidents in countries such as France and Lithuania. The IT's coverage was additionally less alarmist and more measured in its coverage of the disaster.

Concerns (largely quoted from politicians, medical professionals, and environmental non-governmental organization spokespersons) over Sellafield, and the health and safety implications for Ireland should an incident occur featured predominantly in the anti-nuclear sample. For example, one article notably criticized Ireland's Nuclear Energy Board (at that point a decade old agency responsible for radiation monitoring and the potential introduction of nuclear power in Ireland), with resentment and uncertainty towards this agency maintained in subsequent articles (mostly in the form of selected quotes from politicians). Such stories comprised the majority of anti-nuclear articles prior to Chernobyl, demonstrating the Irish media's considerable preoccupation with (and skepticism towards) safety of nuclear power. A notably small sum of articles presented the views and opinions of respective authors in opinion pieces.

A total of 27 articles discussed planning, licensing and supervision (in relation to Chernobyl, Europe and Ireland, and around EEC regulations, food bans/checks and radiation monitoring), and 26 articles referred to commercial nuclear power, concerning future plans and government support for nuclear power infrastructure in Ireland, Europe

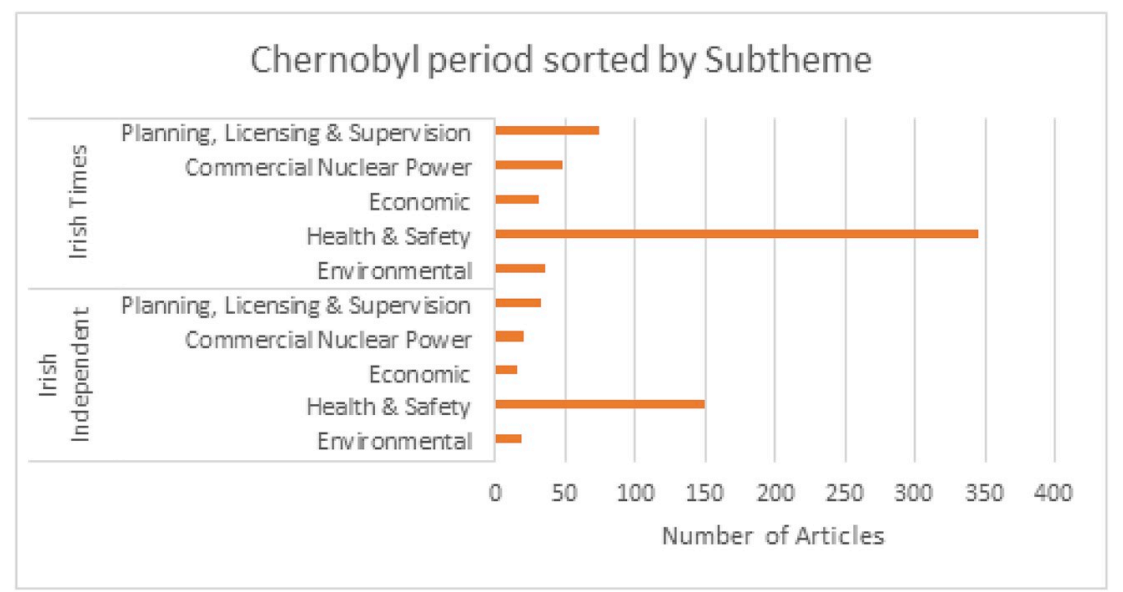

Fig. 4. Number and percentage of articles per subtheme for each newspaper pre- and post-Chernobyl 1986 (adapted from Wang et al., 2014). 
Table 6

Number and percentage of articles per subtheme for each newspaper pre- and post-Chernobyl 1986 (adapted from Wang et al., 2014).

\begin{tabular}{|c|c|c|c|c|c|c|}
\hline Newspaper and Sub-theme & Environmental & Health \& safety & Economic & Commercial nuclear power & Planning, licensing \& supervision & Total \\
\hline \multicolumn{7}{|l|}{ Anti-nuclear } \\
\hline The Irish Independent & $10(11.5 \%)$ & $57(65.5 \%)$ & $1(1.1 \%)$ & $7(8 \%)$ & $12(13.8 \%)$ & 87 \\
\hline The Irish Times & $23(13 \%)$ & $119(67.2 \%)$ & $1(0.6 \%)$ & $19(10.7 \%)$ & $15(8.5 \%)$ & 177 \\
\hline Total & $33(12.5 \%)$ & $176(66.7 \%)$ & $2(0.8 \%)$ & $26(9.8 \%)$ & $27(10.2 \%)$ & 264 \\
\hline \multicolumn{7}{|l|}{ Pro-Nuclear } \\
\hline The Irish Independent & - & $4(80 \%)$ & - & $1(20 \%)$ & - & 5 \\
\hline The Irish Times & - & $6(54.5 \%)$ & $3(27.3 \%)$ & $2(18.2 \%)$ & - & 11 \\
\hline Total & - & $10(62.5 \%)$ & $3(18.8 \%)$ & $3(18.8 \%)$ & - & 16 \\
\hline \multicolumn{7}{|l|}{ Balanced } \\
\hline The Irish Independent & $1(5 \%)$ & $15(75 \%)$ & - & $3(15 \%)$ & $1(5 \%)$ & 20 \\
\hline The Irish Times & $2(4.4 \%)$ & $24(53.3 \%)$ & $3(6.7 \%)$ & $9(20 \%)$ & $7(15.6 \%)$ & 45 \\
\hline Total & $3(4.6 \%)$ & $39(60 \%)$ & $3(4.6 \%)$ & $12(18.5 \%)$ & $8(12.3 \%)$ & 65 \\
\hline \multicolumn{7}{|l|}{ Informational } \\
\hline The Irish Independent & $8(6.3 \%)$ & $74(58.3 \%)$ & $15(11.8 \%)$ & $10(7.9 \%)$ & $20(15.7 \%)$ & 127 \\
\hline The Irish Times & $11(3.6 \%)$ & $197(65.2 \%)$ & $24(7.9 \%)$ & $18(6 \%)$ & $52(17.2 \%)$ & 302 \\
\hline Total & $19(4.4 \%)$ & $271(63.2 \%)$ & $39(9.1 \%)$ & $28(6.5 \%)$ & $72(16.8 \%)$ & 429 \\
\hline
\end{tabular}

and Britain. Thirty-three anti-nuclear articles expressed concerns over the environmental implications of nuclear power generation. The bulk of anti-nuclear environmental articles were a mixture of stories about Chernobyl's impact on air quality and biodiversity in Europe and Sellafield's purported impact on the Irish Sea. Only two articles focused on the economic costs (Table 6).

\subsection{Pro-nuclear articles}

Sixteen articles on Chernobyl over the seven-month study period were pro-nuclear (Table 6). As was the case in the anti-nuclear category, virtually no pro-nuclear articles voiced the author's own views, demonstrating a deficit of opinion pieces and editorials with respect to nuclear power and Chernobyl. The Irish Times once again displayed a more global focus and presented a greater variety of themes, additionally broaching economic and industrial concerns.

Ten articles focused on health and safety particularly at the UKbased Sellafield facility, emphasizing the safety of nuclear power generation due to infrastructural improvements, while making the claim of scaremongering regarding concerns over Sellafield in Ireland. Pro-nuclear articles also presented the positive views of Soviet leaders on Chernobyl and nuclear power, and focused on the economic advantages of nuclear power, citing the opinions of the British Energy Secretary and the UK Atomic Energy Authority. It was argued here that eradicating nuclear power in Britain would lead to significant unemployment and hinder the economic and infrastructural development of lowand middle-income countries.

\subsection{Balanced articles}

Balanced articles, of which there were sixty-five, frequently included articles related to health and safety, but also topics on commercial nuclear power, planning, licensing and supervision, and environmental subthemes. All but two balanced articles were printed after April 26, evincing a lack of concerted, non-event-based discourse regarding the merits and shortfalls of nuclear energy in both newspapers.

The bulk of balanced articles were health and safety, regarding safe radiation levels and the safety of nuclear power plants, particularly those in Britain. Other articles examined views relating to the tenability of the nuclear power industry and the need for stronger regulations and supervision. Overall, balanced articles were marginally less contingent on opinion quotes than pro- and anti-nuclear categories and more premised on fact.

\subsection{Informational articles}

Articles that were informational in content generally focused on health and safety issues (271), with a particular emphasis on the effects of Chernobyl in Ireland and wider Europe, and in terms of how countries monitor health and safety risks. This was followed by planning, licensing and supervision (72), economic (39), commercial (28), and environmental (19). Informational articles covered broadly the same topics as pro-nuclear, anti-nuclear and balanced articles but exhibited more consistent coverage of the Chernobyl disaster, Sellafield and planning, licensing and supervision-related concerns. Many of the incidents reported in informational articles are referenced in pro-nuclear, anti-nuclear and balanced articles.

\section{Fukushima}

\subsection{Overview}

In news articles pre- and post- Fukushima, health and safety, and economic sub-themes prevail (Figs. 5 and 6). The differences in subtheme coverage were more pronounced, with health and safety articles significantly more prevalent in II.

\subsection{Anti-nuclear articles}

All 'anti-nuclear' articles observed in the specified period were printed after the Fukushima incident. The greatest number focused on health and safety concerns (84) (Table 7). Articles focusing primarily on the incident refer to disaster ramifications and protective/remedial measures (e.g. evacuations and contamination screening), contrasting with the government and nuclear industry position with what was actually unfolding. A considerable number of such articles comprised human interest pieces (largely absent during Chernobyl). In the week following Fukushima, articles looking at the various impacts of the disaster overseas emerged and remained frequent in the months that followed, the sub-themes economic and commercial nuclear power were especially prevalent in this regard. These articles referred to growing 'anti-nuclear' sentiment in countries such as Germany, and called for the cessation of nuclear power programs. These articles also focused on the disaster's effect in Europe and measures taken by governments concerning their own industries. Stories relevant to Ireland mainly centered on Sellafield; how it continues to attract the ire of campaigners and the Irish government.

Among the other anti-nuclear articles, there were 7 on planning, licensing and supervision, 18 on the commercial nuclear power, and 12 on economic aspects. The IT in particular, focused on the political dimensions and ramifications of the disaster for Japan (e.g. political casualties of disaster, statements by leaders) and greater attention was paid to its implications overseas (as evidenced by the number of planning, licensing and supervision articles) as well as current sentiments towards/status of global nuclear industries. Only three anti-nuclear articles featured the environmental implications, focusing on air and water quality concerns. 


\section{Fukushima period sorted by theme}

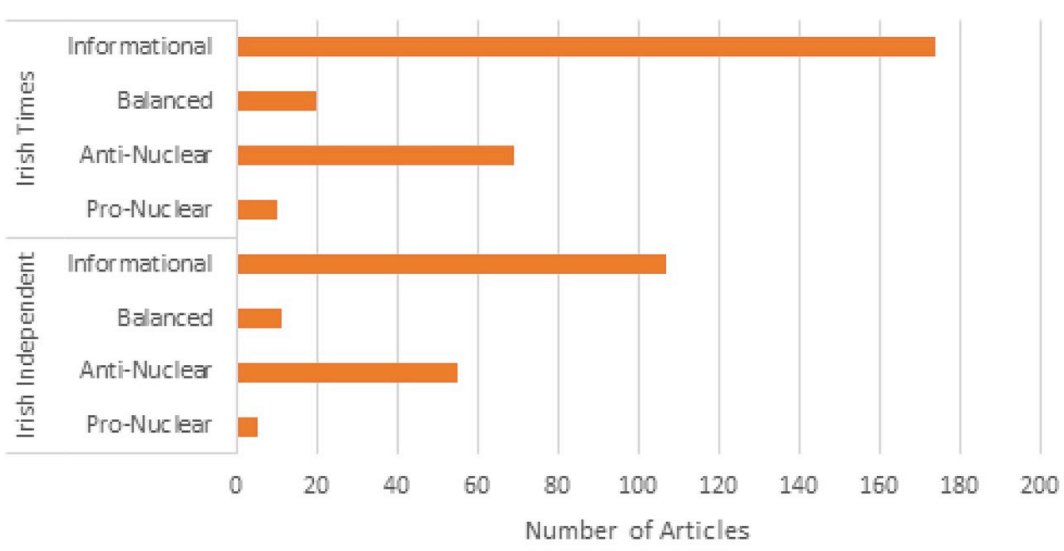

Fig. 5. Frequency of articles presenting pro-nuclear, anti-nuclear, balanced and informational themes in each newspaper pre- and post-Fukushima 2011 (adapted from Wang et al., 2014).

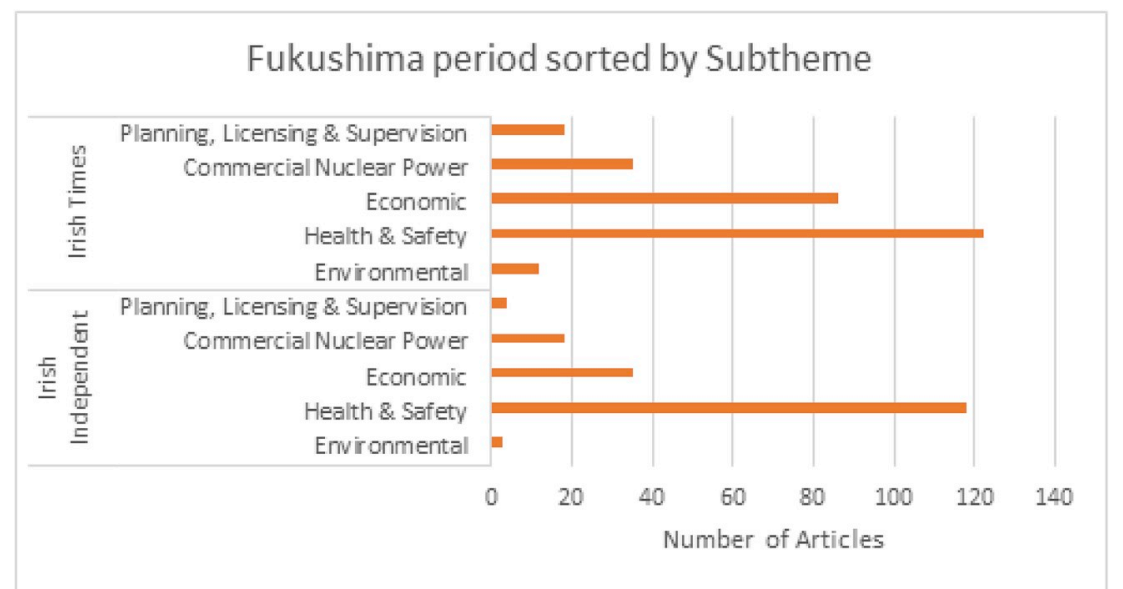

Fig. 6. Number and percentage of articles per subtheme for each newspaper pre- and post-Fukushima 2011 (adapted from Wang et al., 2014).

\subsection{Pro-nuclear articles}

Pro-nuclear articles were mostly opinion pieces that focused on Ireland and disparaged the Irish government and 'anti-nuclear' campaigners, accusing them of being alarmist towards nuclear power. The substantial increase in opinion pieces represents the only noticeable shift in article type frequency between Chernobyl and Fukushima, with other types, e.g. feature articles, remaining broadly the same in occurrence.

Fifteen articles were pro-nuclear in the Fukushima sample, with the greatest number occurring in the month after the Fukushima incident.

Table 7

Number and percentage of articles per subtheme for each newspaper pre- and post-Fukushima 2011 (adapted from Wang et al., 2014).

\begin{tabular}{|c|c|c|c|c|c|c|}
\hline Newspaper and Sub-theme & Environmental & Health \& safety & Economic & Commercial nuclear power & Planning, licensing \& supervision & Total \\
\hline \multicolumn{7}{|l|}{ Anti-nuclear } \\
\hline The Irish Independent & $1(1.8 \%)$ & $40(72.7 \%)$ & $6(10.9 \%)$ & $8(14.5 \%)$ & - & 55 \\
\hline The Irish Times & $2(2.9 \%)$ & $44(63.8 \%)$ & $6(8.7 \%)$ & $10(14.5 \%)$ & $7(10.1 \%)$ & 69 \\
\hline Total & $3(2.4 \%)$ & $84(67.7 \%)$ & $12(9.7 \%)$ & $18(14.5 \%)$ & $7(5.6 \%)$ & 124 \\
\hline \multicolumn{7}{|l|}{ Pro-Nuclear } \\
\hline The Irish Independent & $1(20 \%)$ & $2(40 \%)$ & - & $2(40 \%)$ & - & 5 \\
\hline The Irish Times & $3(30 \%)$ & $6(60 \%)$ & - & $1(10 \%)$ & - & 10 \\
\hline Total & $4(26.7 \%)$ & $8(53.3 \%)$ & & $3(20 \%)$ & & 15 \\
\hline \multicolumn{7}{|l|}{ Balanced } \\
\hline The Irish Independent & - & $7(63.6 \%)$ & $2(18.2 \%)$ & $1(9.1 \%)$ & $1(9.1 \%)$ & 11 \\
\hline The Irish Times & $1(5 \%)$ & $5(25 \%)$ & $1(5 \%)$ & $8(40 \%)$ & $5(25 \%)$ & 20 \\
\hline Total & $1(3.2 \%)$ & $12(38.7 \%)$ & $3(9.7 \%)$ & $9(29 \%)$ & $6(29 \%)$ & 31 \\
\hline \multicolumn{7}{|l|}{ Informational } \\
\hline The Irish Independent & $1(0.9 \%)$ & $69(64.5 \%)$ & $27(25.2 \%)$ & $7(6.5 \%)$ & $3(2.8 \%)$ & 107 \\
\hline The Irish Times & $6(3.4 \%)$ & $67(38.5 \%)$ & $79(45.4 \%)$ & $16(9.2 \%)$ & $6(3.4 \%)$ & 174 \\
\hline Total & $7(2.5 \%)$ & $136(48.4 \%)$ & $106(37.7 \%)$ & $23(8.2 \%)$ & $9(3.2 \%)$ & 281 \\
\hline
\end{tabular}


Of these fifteen articles, eight were predicated on health and safety; nuclear was framed as safe, cost-effective, and reliable and the optimum choice for renewable energy and climate change mitigation. Three articles were commercial; none were economic. In contrast to Chernobyl, the environmental sub-theme was a feature in four articles. Also unlike Chernobyl, 'pro-nuclear' articles printed during Fukushima were less concerned with the international focus and more concerned with Ireland (for e.g. articles in the IT were critical of the Irish government's negative stance towards nuclear) (Table 7).

\subsection{Balanced articles}

Most balanced articles focused on health and safety issues (12) which emerged in the week after the accident, and looked at the effects of the disaster in terms of radiation levels, and how other countries have responded (e.g., emergency aid and policy rethinks; whether or not governments ordered stress tests and/or cessation of nuclear power production.). This was followed by commercial nuclear power (9), planning, licensing and supervision (6) and economic (3) sub-themes. One article focused on the environment.

The balanced category comprised articles that incorporate the views of various experts (both overseas and in Japan), politicians and members of the public on the disaster with updates on current relief efforts. Arguments mainly focus around the severity of the disaster and its impacts (both in Japan and abroad), with marked diversity in terms of sub-theme. Several articles attempted to present and encourage an informed debate on nuclear and the nuclear industry, in marked contrast to the balanced articles observed during Chernobyl. While climate change was mentioned in conjunction with nuclear on several occasions, it was rarely elaborated upon. In the IT, a recurring theme (with the exception of Germany) was the willingness of countries such as Russia and the US to persevere with nuclear power, despite clear admittance of domestic and global safety issues and the need for greater regulation and general uncertainty from both experts and journalists.

\subsection{Informational articles}

Health and safety themes dominated informational articles during the Fukushima period (136). In comparison to the Chernobyl incident, the economic ramifications of Fukushima (especially globally) received considerable attention (106 articles), looking at the effects of the incident on global markets (and, to a lesser extent, Japan's economy). Again, in comparison to Chernobyl, there were fewer informational articles covering commercial nuclear power (23) and the sub-themes of planning, licensing and supervision (9).

Seven informational articles focused on the environment. A small number of articles mention the potential of nuclear power in conjunction with renewable energy. Several times, articles referenced nuclear power in conjunction with climate change - but not specifically in relation to Ireland. Media articles presented nuclear power as playing a potentially important role towards reducing greenhouse gas emissions, but articles acknowledged that the Fukushima incident could undermine existing plans to expand nuclear in countries that take a pro-nuclear stance. Significantly, one of several articles published before March 11 - the date of the incident - referred to the need to start discussing the subject of nuclear power in Ireland for energy reasons.

\section{Discussion}

\subsection{Overview}

The media plays an important role in communicating risk, translating science and policy, and reflecting public opinion. Within this role, media frames are used as an effective communication tool. Topic selection and salience are central in the framing process, and the efficiency of frames often depends on the absence of alternative information being communicated. This is important as the way the media portrays nuclear power will have a significant impact on public perception, and public acceptance, of nuclear power. For example, the 'alarmist' portrayal of nuclear, particularly in the II for Chernobyl, represents nuclear as something 'out of control'.

This paper set out to identify how nuclear power is framed in sections of Ireland's two main broadsheet papers, and to consider the implications for how nuclear is perceived and for wider debates on Ireland's transition to a low carbon economy. We selected two major nuclear incidents - Chernobyl and Fukushima - and took a longitudinal approach to help identify any shift that may have taken place in media framing of nuclear in Ireland. Allowing for a range of media frames to emerge, a seven-month study period was applied for each incident: one month prior to the incident, the month of the incident, and five months after. As outlined earlier, the thematic coding structure used by Wang et al. (2014) was applied to the data-set and adapted where necessary to reflect emerging themes.

Coverage for both incidents peaked around and in the immediate aftermath of the incident date. This is in line with reporting patterns observed elsewhere (Shehata \& Hoppmann, 2012; Kleinschmit \& Sjostedt, 2014). Overall, despite a twenty-five year time period between incidents, there was no real dramatic change in how nuclear power is being framed in the Irish media. However, in 2011, both newspapers widened their economic coverage, reflecting perhaps the focus on the global (including Ireland's) economic recession during which Fukushima took place.

In terms of the predominance of health and safety concerns in media coverage, our results support Koerner's analysis (2014) of media framing of three nuclear incidents. Koerner's analysis also revealed a strong emphasis on environmental implications, however, thematically, the environment as a topic was categorized alongside health. Articles within the environmental sub-theme in this paper remained under ten percent in general for coverage of both incidents. There are also differences between our results and those observed by Wang et al. (2014). Wang et al. observed that articles were predominantly pro-nuclear, focusing on the environmental benefits, in line with the government's position on the use of nuclear to address climate change and reduce environmental pollution, as well as safety - to help appease concerns arising from the Fukushima incident. Of course, these differences can be somewhat explained by differences in the relationship between media and the government in China. This paper goes beyond Wang et al. (2014)'s statistical analysis of categorizations by exploring in-depth the qualitative meaning and sentiment in the articles, for example the focus on human interest pieces for Fukushima. It is perhaps not surprising that in a centrally planned country such as China, where media is closely controlled by the state, opinion pieces that reflect a wide diversity of views and human interest articles are largely absent.

In their media analysis, Culley et al. (2010) observed that health and safety concerns were among the least represented in coverage of proposed nuclear reactors in parts of the United States. However, as in our study, Culley et al. (2010) reported that thematically, balanced and informational stories featured widely. They question the extent to which informational frames are 'neutral' - arguing instead that by failing to report on the environmental, economic and social risks, informational articles are adopting a pro-nuclear stance.

\subsection{Societal and policy implications}

Wang et al. (2014) argue that open media is important for improving public awareness and generating public support on energy policy. Nuclear, as well as climate change, especially within the context of what Pidgeon et al. (2008) identify as 'energy futures', are complex topics that therefore require balanced and full debates (Pidgeon et al., 2008; Koerner, 2014; Wang et al., 2014).

Koerner (2014) finds that media framing of nuclear is "highly consistent" with government policy on nuclear power. The prevalence 
of informational and balanced articles across both samples suggest that to some extent, an open debate on nuclear is already taking place in Ireland. Nevertheless, the number of pro-nuclear articles pales in comparison to the number of anti-nuclear articles, reflecting the lack of political and public appetite for nuclear power generation in Ireland. Arguably, this imbalance may limit the potential for a much wider and open debate to take place on how the energy sector can contribute to reducing domestic $\mathrm{CO} 2$ emissions; in the context of an urgent need to address climate change. Our analysis also shows how nuclear governance in third countries impacts on the acceptability of nuclear power at home, with Sellafield impacting in Ireland, and Fukushima and Chernobyl impacting globally.

Of greatest interest to the authors is the extent to which environmental implications, and in particular, the role of nuclear in climate change mitigation, is discussed. Results show that health and safety concerns are at the forefront of the media conversation. The environmental sub-theme featured in less than ten percent of total articles in 1986 and less than 5 percent of total articles in 2011 - a finding that differs from the prevalence of the environmental theme in media analyses conducted elsewhere (Culley et al., 2010; Wang et al., 2014). Where present (i.e. in pro-nuclear and balanced articles during the Fukushima time-period), the potential advantages of nuclear were attributed to mitigating climate change but featured only in a small number of articles, where it was generally given little attention. This paucity, in part, may be explained by the overall lack of focus on climate change in the Irish mainstream media, with content analyses suggesting that climate change as a topic has been marginalized and is segregated from related topics such as flooding, energy, and the economy (Fox and Rau, 2016). Carvalho and Burgess's (2005) analysis of media coverage of climate change in the UK found that a number of broadsheet newspapers reported on global warming between 1985 and 2003. In the last two decades however, scientific, political and public awareness of climate change has increased, and in terms of the policy landscape in Ireland, climate and energy have become more prevalent as an area of policy focus. This same focus has not necessarily manifested itself through increased Irish media coverage. In media cases where nuclear power has been framed as a solution to climate change mitigation, this often results in a shift towards public acceptance (Corner et al., 2011; Morrone et al., 2012). However, opposition towards nuclear can remain even when nuclear is regarded by the public as a viable option for mitigating climate change (Pidgeon et al., 2008; Bird et al., 2014).

\section{Conclusion}

We argue that a limited focus on the environmental implications of nuclear - negative and positive - presents a missed opportunity to commence a more comprehensive and open debate, among politicians and the public, on:

- the long-term sustainability of Ireland's current energy mix given the shift away from fossil fuels in an EU context

- the environmental advantages and disadvantages of including nuclear power generation in Ireland's energy mix, as it seeks to transition to a low carbon economy

- the renewable energy alternative(s) to nuclear power that requires implementation to achieve a low carbon economy, should nuclear power continue to be unacceptable to the Irish public

- the role nuclear power generation can potentially play in mitigating climate change nationally and internationally, particularly by the United Kingdom. This is pertinent as the challenges of realizing the global temperature goals established by the Paris Agreement become ever more apparent

- how Ireland compares with other similar EU countries where nuclear power generation is currently absent to gauge media influence on public perceptions.

Although there is currently legislation prohibiting nuclear power generation in Ireland, a (small) proportion of Ireland's electricity supply is generated by nuclear in the United Kingdom. This polarization between a policy of prohibition on the generation of nuclear electricity on the one hand, and the importation of nuclear-powered electricity through a linked grid system on the other, raises questions around policy consistency. Considering the urgency of climate change and, as Ireland seeks to reduce emissions by 80 percent before 2050, a balanced and full societal debate on the contribution of nuclear power to climate policy is necessary, particularly since alternative sources of energy have faced much opposition in an Irish context. Despite improvements in nuclear power generation, development in climate and energy policy direction at a EU scale, and greater awareness (and policy action) on climate change mitigation, this paper shows that over two time frames (circa. 25 years) there has been little change in the framing of nuclear in the Irish mainstream media. An absence of any considerable environmental focus presents a missed opportunity to increase public awareness on climate change and energy in Ireland.

\section{Acknowledgements and funding}

This research did not receive any specific grant from funding agencies in the public, commercial, or not-for-profit sectors.

\section{Appendix A. Supplementary data}

Supplementary data to this article can be found online at https://doi.org/10.1016/j.pnucene.2018.09.024.

\section{Appendix}

Sample articles for each theme and each subtheme after the coding rules were applied.

Table A1

Themes and coding rules (adapted from Wang et al., 2014).

\begin{tabular}{|c|c|}
\hline Theme & Coding rule \\
\hline Pro-nuclear & $\begin{array}{l}\text { "Nuclear energy carries risks, as does aviation, but we still persist because, on the balance of evidence, we reason that the benefits } \\
\text { outweigh the risks. Despite extraordinary alarmism over Fukushima, how many people will die in the next 10-20 years as a result } \\
\text { of radiation from this incident? Five? Ten? Zero? On the other hand, at least three million people will die this year as a result of air } \\
\text { pollution. That's more than } 8000 \text { people every day. The principle source is airborne particulates arising from the wide-scale } \\
\text { mining and burning of fossil fuels." (More power to us if we choose nuclear option. The Irish Times, 25 August 2011). }\end{array}$ \\
\hline
\end{tabular}


Table A1 (continued)

\begin{tabular}{ll}
\hline Theme & Coding rule \\
\hline Anti-nuclear & "An Alliance government in Britain would not go ahead with the Sizewell nuclear reactor, the Liberal leader, Mr David Steel, said \\
& yesterday. He accused the Government of being 'all over the place' in its reaction to the Chernobyl disaster. The Energy Secretary, \\
& Mr Peter Walker, and Environment Minister, Mr William Waldegrave, were at odds with each other. At a by-election rally in \\
& Wirksworth, West Derbyshire, he said: 'Mr Walker wants to press ahead with new nuclear stations and Mr Waldegrave wants to \\
& restrain him. Decisions on the burial of nuclear waste have been hurriedly changed'. Britain must not become nuclear energy \\
& dependent, he said." (Alliance rejects Sizewell nuclear reactor. The Irish Times, 6 May 1986). \\
& "Mr. Oettinger said that 'stress' testing was needed to ensure that Europe's 143 reactors could withstand earthquakes and other \\
& emergencies. 'We want the safety of all reactors to be reviewed in the light of events in Japan' he said. 'It has to raise the question \\
& of whether we in Europe, in the foreseeable future, can secure our energy needs without nuclear power'. Chris Huhne, Britain's \\
& energy minister, said he regretted 'the fact that some continental politicians do seem to be rushing to judgment before we have \\
had the proper assessment'. 'We take this incident extremely seriously even though there is no reason to expect a similar scale of \\
seismic activity in the UK'." (Europe's reactors face natural disaster testing. The Irish Independent, 16 March 2011). \\
"Levels of radiation are measured in relation to the amount of damage they can cause to living things. A variety of methods are \\
used to determine the amount of damage which a given level of radiation will cause. The unit of measurement is called the \\
Sievert. The absolute maximum dose which is considered safe is 50 thousandths of a Sievert - and this is applied only to workers \\
in nuclear power plants. For the general public, however, the maximum level is only 5/thousandths of a Sievert." (All you ever \\
wanted to know about nuclear energy. The Irish Independent, 7 May 1986).
\end{tabular}

Table A2

Subthemes and coding rules (adapted from Wang et al., 2014).

\begin{tabular}{ll}
\hline Subtheme & Coding rule \\
\hline Environmental & "Plaid Cymru MP Mr. Dafydd Elis-Thomas told the Irish Independent that he has received information from British \\
Department of Energy sources that Caesium 137 levels in parts of the Irish Sea have doubled since Chernobyl. But a \\
statement from the Nuclear Energy Board here said last night there had been 'no detectable increase' in Caesium \\
levels in the Irish Sea as a result of the Chernobyl fall-out. Recent analyses of fish and seawater from the Irish Sea by \\
the board and TCD had confirmed that. 'However, there has been a slight increase in the Caesium levels of seaweed \\
along the Irish coastline due to the fallout which occurred over Ireland during early May. This slight increase is of \\
no radiological significance', the statement said". (Radiation in sea must be cut: MP. The Irish Independent, 17 July \\
1986).
\end{tabular}

Health and safety

"The breast milk of four Japanese mothers has been found to contain small quantities of radioactive iodine, prompting calls for the government to conduct a full investigation into the impact of the nuclear disaster on mothers and babies. The contamination came to light after tests on samples from nine women living north-east or east of Tokyo. Four were found to be contaminated, with the highest reading of 36.3 becquerels of radioactive iodine per kg detected in the milk of the mother of an eight-month-old in Kashiwa, Chiba prefecture. There are no current legal safety levels for radioactive substances in breast milk as set by the Nuclear Safety Commission of Japan". (Four Japanese mothers show traces of radioactive milk. The Irish Independent, 22 April 2011).

Economic "Asian stocks slipped yesterday, as Beijing's tightening moves weighed on the Shanghai Composite index, but the Tokyo market made progress on growth hopes for exporters. For the second day in a row, however, the star performer was Tokyo Electric Power, the utility at the centre of Japan's nuclear reactor crisis. Tepco's stock extended Tuesday’s 25 per cent gains by a further 32 per cent to $¥ 392$. The government said on Tuesday that it would help the utility with compensation payments to those affected by nuclear leaks.". (Tokyo bucks weak trend in regions' stocks. The Irish Times, 16 June 2011).

Planning, licensing and "The EEC's non-nuclear countries yesterday expressed concern about the siting of nuclear power plants in supervision neighbouring countries. The Minister of State at the Department of Foreign Affairs, Mr George Birmingham, said that the Council of Ministers had approved without discussion the final draft of a document on EEC energy objectives up to 1995. But he had referred briefly to Ireland's concern about nuclear safety which would be repeated at every opportunity. Ireland, along with Greece, Luxembourg, Portugal and Denmark, had failed to get their concerns about the siting of nuclear plants written into the main energy policy guidelines. However, their separate political declaration said that they understood a call for maximum security in the planning, construction and operation of nuclear plants to include as an essential element the siting of such plants, especially their distance from national borders of densely populated areas." (Non-nuclear states join in concern. The Irish Times, 17 September 1986).

Commercial nuclear power "Unperturbed by Three Mile Island, Chernobyl and minor mishaps at home, France is pursuing a nuclear power programme which already supplies nearly 75 percent of its electricity needs. Other counties - Canada, Japan, the United States - generate more nuclear energy but none approaches this proportion of overall consumption. The French people have learned to live with the gigantic chimneys which belch swirling white clouds into the sky, while cattle graze peacefully in surrounding fields. At several plants, excess heat is harnessed to local uses - heating apartment blocks or greenhouses in market gardens." (France at home with N-power. The Irish Times, 8 September 1986). 


\section{References}

Allan, S., 2002. Media, Risk and Science. Open University Press, Buckingham.

Altheide, D.L., Schneider, C.J., 2012. Qualitative Media Analysis, second ed. SAGE, Thousand Oaks, CA.

Batty, C., Cain, S., 2016. Media Writing: a Practical Introduction, second ed. PALGRAVE, London.

Bayulgen, O., Arbatli, E., 2013. Cold War redux in US-Russia relations? The effects of US media framing and public opinion of the 2008 Russia-Georgia war. Commun. Post Commun. Stud. 46, 513-527. https://doi.org/10.1016/j.postcomstud.2013.08.003.

Bibas, R., Méjean, A., Hamdi-Cherif, M., 2015. Energy efficiency policies and the timing of action: an assessment of climate mitigation costs. Technol. Forecast. Soc. Change 90, 137-152. https://doi.org/10.1016/j.techfore.2014.05.003.

Bird, et al., 2014. Nuclear power in Australia: A comparative analysis of public opinion regarding climate change and the Fukushima disaster. Energy Pol. Vol. 65, 644-653.

Boykoff, M.T., Rajan, S.R., 2007. Signals and noise: mass media coverage of climate change in the USA and the UK. EMBO Rep. 8, 207-211.

Boykoff, M.T., Roberts, J.T., 2007. Media coverage of climate change: current trends, strengths, weaknesses. Retrieved May 20, 2017, from: http://hdr.undp.org/sites/ default/files/boykoff_maxwell_and_roberts_j.timmons.pdf.

Bruckner, T., Bashmakov, I.A., Mulugetta, Y., Chum, H., de la Vega Navarro, A., Edmonds, J., Faaij, A., Fungtammasan, B., Garg, A., Hertwich, E., Honnery, D., Infield, D., Kainuma, M., Khennas, S., Kim, S., Nimir, H.B., Riahi, K., Strachan, N., Wiser, R., Zhang, X., 2014. Energy systems. In: Edenhofer, O., Pichs-Madruga, R., Sokona, Y., Farahani, E., Kadner, S., Seyboth, K., Adler, A., Baum, I., Brunner, S., Eickemeier, P., Kriemann, B., Savolainen, J., Schlömer, S., von Stechow, C., Zwickel, T., Minx, J.C. (Eds.), Climate Change 2014: Mitigation of Climate Change. Contribution of Working Group III to the Fifth Assessment Report of the Intergovernmental Panel on Climate Change. Cambridge University Press, Cambridge, United Kingdom and New York, NY, USA.

Cannon, Terry, Müller-Mahn, Detlef, 2010. Vulnerability, resilience and development discourses in context of climate change. Natural Hazards 55 (3) Springer: Germany.

Carvalho, A., Burgess, J., 2005. Cultural circuits of climate change in UK broadsheet newspapers, 1985- 2003. Risk Anal. 25, 1457-1469. https://doi.org/10.1111/j. 1539-6924.2005.00692.x.

Castrechini, A., Pol, E., Guàrdia-Olmos, J., 2014. Media representations of environmental issues: from scientific to political discourse. Rev. Eur. Psychol. Appl. 64, 213-220. https://doi.org/10.1016/j.erap.2014.08.003.

Chester, L., 2010. Conceptualising energy security and making explicit its polysemic nature. Energy Pol. 38 (2), 887-895.

Climate Advisory Council, 2016. Climate Change Advisory Council First Report. Retrieved May 15, 2017, from: http://www.climatecouncil.ie/media/CCAC FIRSTREPORT.pdf.

Cooper, M., 2016. The Economic and institutional foundations of the paris agreement on climate change: the political economy of roadmaps to a sustainable electricity future. Retrieved May 15, 2017, from: https://ssrn.com/abstract $=2722880$.

Corner, A., Venables, D., Spence, A., Poortinga, W., Demski, C., Pidgeon, N., 2011. Nuclear power, climate change and energy security: exploring british public attitudes. Energy Pol. 39, 4823-4833. https://doi.org/10.1016/j.enpol.2011.06.037.

Culley, M., Angelique, H., 2011. Participation, power, and the role of community psychology in environmental disputes: a tale of two nuclear cities. Am. J. Community Psychol. 47, 410-426. https://doi.org/10.1007/s10464-010-9395-9.

Culley, M.R., Ogley-Oliver, E., Carton, A.D., Street, J.C., 2010. Media framing of proposed nuclear reactors: an analysis of print media. J. Community Appl. Soc. Psychol. 20, 497-512. https://doi.org/10.1002/casp.1056.

Curtis, J., Morgenroth, E., Coyne, B., 2016. The Potential Economic Impact of a Nuclear Accident - an Irish Case Study. Economic and Social Research Institute, Dublin Retrieved May 4, 2017, from: http://www.dccae.gov.ie/en-ie/news-and-media/ publications/Documents/17/The\%20potential\%20economic\%20impact\%20of\%20a $\% 20$ nuclear\%20accident $\% 20-\% 20$ An $\% 20$ Irish\%20Case $\% 20$ Study $\% 20$ ESRI.pdf.

D'Angelo, P., 2017. Framing: Media Frames. The International Encyclopedia of Media Effectshttps://doi.org/10.1002/9781118783764.wbieme0048.

DeLlano-Paz, F., Calvo-Silvosa, A., Antelo, S.I., Soares, I., 2015. The european low-carbon mix for 2030: the role of renewable energy sources in an environmentally and socially efficient approach. Renew. Sustain. Energy Rev. 48, 49-61. https://doi.org/10. 1016/j.rser.2015.03.032.

Department of Communications, Climate Action \& Environment, 2014. Green Paper on Energy Policy in Ireland. Retrieved May 22, 2017, from: http://www.dccae.gov.ie/ documents/DCENRGreenPaperonEnergyPolicyinIreland.pdf.

Department of Communications, Energy and Natural Resources, 2015. Ireland's transition to a low carbon energy future 2015-2030. Retrieved May 20, 2017, from: http:// www.dccae.gov.ie/energy/SiteCollectionDocuments/Energy-Initiatives/Energy \%20White\%20Paper\%20-\%20Dec\%202015.pdf.

Devitt, C., O'Neill, E., 2016. The framing of two major flood episodes in the Irish print news media: implications for societal adaptation to living with flood risk. Publ. Understand. Sci. 1-17. https://doi.org/10.1177/0963662516636041 pus.sagepub. com.

Doyle, J., 2011. Acclimatizing nuclear? Climate change, nuclear power and the reframing of risk in the UK news media. Int. Commun. Gaz. 73, 107-125. https://doi.org/10. $1177 / 1748048510386744$

Elo, S., Kyngäs, H., 2008. The qualitative content analysis process. J. Adv. Nurs. 62, $107-115$.

Entman, R.M., 1989. How the media affect what people think: an information processing approach. J. Polit. 51, 347-370. https://doi.org/10.2307/2131346.

Entman, R.M., 1991. Framing U.S. Coverage of international news: contrasts in narratives of the KAL and Iran air incidents. J. Commun. 41, 6-27.

Entman, R.M., 1993. Framing: toward clarification of a fractured paradigm. J. Commun 43, 51-58. https://doi.org/10.1111/j.1460-2466.1993.tb01304.x.

Environmental Protection Agency, 2015. Ireland's greenhouse gas emission projections 2014-2035. Retrieved May 10, 2017, from: https://www.epa.ie/pubs/reports/air airemissions/EPA\%202015\%20GHG\%20Projections\%20Publication\%20Final.pdf.

Environmental Protection Agency, 2016. Potential radiological impact on ireland of postulated severe accidents at sellafield. Retrieved May 10, 2017 from: https://www. epa.ie/pubs/reports/radiation/Potential radiological impact Ireland.pdf.

Environmental Protection Agency, 2017. Ireland's greenhouse gas emission projections 2016-2035. Retrieved May 10, 2017, from: http://www.epa.ie/pubs/reports/air/ airemissions/ghgprojections/EPA_2017_GHG_Emission_Projections_Summary_ Report.pdf.

Escobar, M., Demeritt, D., 2014. Flooding and the framing of risk in British broadsheets, 1985-2010. Publ. Understand. Sci. 23, 454-471. https://doi.org/10.1177/ 0963662512457613.

Fitzgerald, J., 2011. A Review of Irish Energy Policy (Report No. 21) Dublin. Economic and Social Research Institute Retrieved May 15, 2017, from: https://www.esri.ie/ pubs/RS21.pdf.

Fox, E., Rau, H., 2016. Climate change communication in ireland. Oxford research encyclopedia of climate science. Retrieved May 10, 2017 from: http://climatescience. oxfordre.com/view/10.1093/acrefore/9780190228620.001.0001/acrefore9780190228620-e-459.

Gamson, A., Modigliani, A., 1989. Media discourse and public opinion on nuclear power: a constructionist approach. Am. J. Sociol. 95, 1-37. https://doi.org/10.1086/ 229213.

Grimes, D., 2015. Ireland's Wind Energy: We Need to Debate the Nuclear Option Honestly. The Irish Times February 24 Retrieved May 22, 2017, from: http://www. irishtimes.com/news/environment/ireland-s-energy-we-need-to-debate-the-nuclearoption-honestly-1.2113299.

Grossman, P.Z., 2015. Energy shocks, crises and the policy process: a review of theory and application. Energy Pol. 77, 56-69. https://doi.org/10.1016/j.enpol.2014.11.031.

Harrower, T., Elman, J.M., 2012. The Newspaper Designer's Handbook, seventh ed. McGraw-Hill Education, New York City, NY.

Helm, D., 2014. The european framework for energy and climate policies. Energy Pol. 64, 29-35. https://doi.org/10.1016/j.enpol.2013.05.063.

Hill, Breen, J.J., 1977. Reporting \& Writing the News. Little, Brown and Company, Boston, MA.

Hsieh, H.F., Shannon, S.E., 2005. Three approaches to qualitative content analysis. Qual. Health Res. 15 (9), 1277-1288.

IPCC, 2014. Climate Change 2014: Mitigation of Climate Change. Contribution of Working Group III to the Fifth Assessment Report of the Intergovernmental Panel on Climate Change. Cambridge University Press, Cambridge, United Kingdom and New York, NY, USA.

Jones, C., Glachant, J.M., 2010. Toward a zero-carbon energy policy in Europe: defining a viable solution. Electr. J. 23, 15-25. https://doi.org/10.1016/j.tej.2010.03.002.

Jupp, V., Norris, C., 1993. Traditions in documentary analysis. In: Hammersley, M. (Ed.), Social Research: Philosophy, Politics and Practice. Sage, London, pp. 37-52.

Kleinschmit, D., Sjöstedt, V., 2014. Between Science and Politics: Swedish Newspaper Reporting on Forests in a Changing Climate. Environ. Sci. Pol. 35, 117-127.

Koerner, C.L., 2014. Media, fear and nuclear energy: a case study. Soc. Sci. J. 51 240-249. https://doi.org/10.1016/j.soscij.2013.07.011.

Kopytko, N., Perkins, J., 2011. Climate change, nuclear power, and the adaptation-mitigation dilemma. Energy Pol. 39, 318-333. https://doi.org/10.1016/j.enpol.2010. 09.046 .

Krippendorff, K., 2003. Content Analysis: an Introduction to its Methodology, second ed. SAGE, Thousand Oaks, CA.

Lazic, D., 2013. News analysis of the fukushima accident: lack of information disclosure, radiation fears and accountability issues. Journal of Contemporary Eastern Asia 12, 19-34. https://doi.org/10.17477/jcea.2013.12.2.019.

Lenzen, M., 2008. Life cycle energy and greenhouse gas emissions of nuclear energy: a review. Energy Convers. Manag. 49 (8), 2178-2199.

Leonard, L., 2006. The Irish Environmental Movement from Carnsore Point to the Rossport Five. Greenhouse Press, Louth.

Macnamara, J., 2005. Media content analysis: its uses; benefits and best practice methodology. Asia Pacific Public Relations Journal 6, 1-34.

Makhijani, A., 2007. Carbon-free and Nuclear-free: a Roadmap for U.S. Energy Policy. Retrieved April 30, 2017, from: http://www.nonukesyall.net/pdfs/ CarbonFreeNuclearFree.pdf.

Morrone, M., Basta, T.B., Somerville, J., 2012. Framing the national nuclear legacy at the local level: implications for the future of federal facilities. Energy Pol. 43, 145-152. https://doi.org/10.1016/j.enpol.2011.12.042.

National Newspapers of Ireland, 2015. JNRS 2012/2013-Readership. Available at: http://nni.ie/jnrs-20122013.

Neresini, F., Lorenzet, A., 2014. Can media monitoring be a proxy for public opinion about technoscientific controversies? The case of the Italian public debate on nuclear power. Publ. Understand. Sci. 25, 171-185. https://doi.org/10.1177/ 0963662514551506.

New Nuclear Watch, 2015. Nuclear energy is essential for decarbonisation and sustainable energy development in Europe. Retrieved May 25, 2017, from: https://www. theparliamentmagazine.eu/articles/partner_article/nuclear-energy-essentialdecarbonisation-and-sustainable-energy-development.

Nuclear Energy Agency, 2015. Technology roadmap: nuclear energy. Retrieved from: https://www.iea.org/media/freepublications/technologyroadmaps/ TechnologyRoadmapNuclearEnergy.pdf.

OECD (Organization for Economic Co-operation and Development), 2010. Comparing 
nuclear accident risks with those from other energy sources. Retrieved from: http:// www.oecd-nea.org/ndd/reports/2010/nea6861-comparing-risks.pdf.

Pan, Z., Kosicki, G.M., 1993. Framing analysis: an approach to news discourse. Polit. Commun. 10, 55-75.

Paska, J., Surma, T., 2014. Electricity generation from renewable energy sources in Poland. Renew. Energy 71, 286-294.

Perko, T., Turcanu, C., Carlé, B., 2012. Media reporting of nuclear emergencies: the effects of transparent communication in a minor nuclear event. J. Contingencies Crisis Manag. 20, 52-63.

Pfenninger, S., Keirstead, J., 2015. Renewables, nuclear, or fossil fuels? Scenarios for great britain's power system considering costs, emissions and energy security. Appl. Energy 152, 83-93.

Pidgeon, N., Lorenzoni, I., Poortinga, W., 2008. Climate change or nuclear power - No thanks! A quantitative study of public perceptions and risk framing in Britain. Global Environ. Change 18, 69-85.

Prati, G., Zani, B., 2012. The effect of the Fukushima nuclear accident on risk perception, antinuclear behavioral intention, attitude, trust, environmental beliefs, and values. Environ. Behav. 45, 782-798.

Rockström, J., Schellnhuber, H.J., Hoskins, B., Ramanathan, V., Schlosser, P., Brasseur, G., Gaffney, O., Nobre, C., Meinshausen, M., Rogelj, J., Lucht, W., 2016. The worlds biggest gamble. Earth's Future 4, 465-470.

Rogeli, J., den Elzen, M., Höhne, N., Fransen, T., Fekete, H., Winkler, H., Schaeffer, R. Keywan, S., Meinshausen, M., 2016. Paris Agreement climate proposals need a boost to keep warming well below $2{ }^{\circ} \mathrm{C}$. Nature 534, 631-639.

Rose, S., Richels, R., Blandford, G., Rutherford, T., 2017. The Paris Agreement and next steps in limiting global warming. Climate Change 142, 225-270.

Schmidt, A., Ivanova, A., Schäfer, M., 2013. Media attention for climate change around the world: a comparative analysis of newspaper coverage in 27 countries. Global Environ. Change 23, 1233-1248.

Shehata, A., Hopmann, D.N., 2012. Framing Climate Change. Journal. Stud. 13 (2), 175-192.

Singer, E., Endreny, P., 1993. Reporting on Risk: How the Mass Media Portray Accidents, Diseases, and Other Hazards. Russell Sage Foundation, New York.

Smith, 2006. Insurmountable Risks: the Dangers of Using Nuclear Power to Combat Global Climate Change. IEER Press, Maryland.
Stephens, J.C., Rand, M.R., Melnick, L.L., 2009. Wind energy in US media: a comparative state level analysis of a critical climate change mitigation technology. Environmental Communication 3, 168-190.

Sustainable Energy Authority of Ireland, 2011. Energy Security in Ireland: a Statistica Overview. Retrieved May 25, 2017, from: http://www.seai.ie/Publications/ Statistics_Publications/Energy_Security_in_Ireland/Energy_Security_in_Ireland_A Statistical_Overview.pdf.

Sustainable Energy Authority of Ireland, 2016. Energy in Ireland 1990-2015. Retrieved May 25, 2017, from: http://www.seai.ie/Publications/Statistics_Publications/ Energy_in_Ireland/Energy-in-Ireland-1990-2015.pdf.

Tankard Jr., J.W., 2001. The empirical approach to the study of media framing. In: Reese, S.D., Gandy Jr.O.H., Grant, A.E. (Eds.), Framing Public Life: Perspectives on Media and Our Understanding of the Social World. Lawrence Erlbaum, Mahwah, NJ.

Teräväinen, T., Lehtonen, M., Martiskainen, M., 2011. Climate change, energy security, and risk - debating nuclear new build in Finland, France and the UK. Energy Pol. 39, 3434-3442.

The International Atomic Energy Agency, 2016. Climate Change and Nuclear Power. International Atomic Energy Agency, Vienna Retrieved from May 25, 2017, from: http://www-pub.iaea.org/MTCD/Publications/PDF/CCANP16web-86692468.pdf.

Ryan calls for public nuclear energy debate. (2008, January 10). The Irish Times. Retrieved May 11, 2017, from: http://www.irishtimes.com/news/ryan-calls-forpublic-nuclear-energy-debate-1.817080.

United Nations Framework Convention on Climate Change, 2015. Adoption of the Paris Agreement, 21st Conference of the Parties. United Nations, Paris.

Wagner, P., Payne, D., 2015. Trends, frames and discourse networks: analysing the coverage of climate change in Irish newspapers. Ir. J. Sociol. 25, 5-28.

Wang, Y., Li, N., Li, J., 2014. Media coverage and government policy of nuclear power in the people's republic of China. Prog. Nucl. Energy 77, 214-223.

Weber, R.P., 1990. Basic Content Analysis. Sage, California.

Wittneben, B.B.F., 2012. The impact of the Fukushima nuclear accident on European energy policy. Environ. Sci. Pol. 15, 1-3.

World Nuclear News, 2015. Nuclear remains Spain's largest electricity supplier. Retrieved May 25, 2017, from:http://www.world-nuclear-news.org/NP-Nuclearremains-Spains-largest-electricity-supplier-1007154.html . 